\title{
Formation of 1-Deoxy-D-threo-pentulose and 1-Deoxy-L-threo- pentulose by Cell-free Extracts of Microorganisms
}

\author{
Akira YокотA and Ken-ichi SASAJIMA \\ Institute for Fermentation, Osaka, 17-85, Juso-honmachi, \\ 2-chome, Yodogawa-ku, Osaka 532, Japan
}

Received July 13, 1983

\begin{abstract}
A new enzymatic acyloin-type condensation between pyruvate (or acetoin or methylacetoin) and D-glyceraldehyde was found to be catalyzed by cell-free extracts of a transketolase mutant of Bacillus pumilus IFO 12089. The reaction product (1) was isolated and determined to be 1-deoxy-Dthreo-pentulose (D-DTP), which is considered to be a precursor of the five-carbon unit of the thiazole ring thiamine. 1-Deoxy-L-threo-pentulose (L-DTP, 2) was synthesized similarly when Lglyceraldehyde was used instead of D-glyceraldehyde. The configurations of $\mathbf{1}$ and $\mathbf{2}$ were confirmed by reduction to the corresponding 1-deoxy-pentitols.

Similar enzyme activities were also detected in cell-free extracts of all the wild-type strains tested of bacteria, actinomycetes, yeasts, and molds. These results suggest that the D-DTP synthesizing enzyme plays an important role in the biosynthesis of the thiazole ring of thiamine in vivo.
\end{abstract}

While studying the mechanism of 1-deoxyD-altro-heptulose formation in a transketolase mutant of Bacillus pumilus, ${ }^{1,2)}$ we found that a partially purified enzyme preparation of the mutant also contained D-DTP synthesizing activity, which catalyzes an acyloin-type condensation between D-glyceraldehyde and pyruvate, DL-acetoin, or methylacetoin (2hydroxy-2-methyl-3-butanone). By a similar method using L-glyceraldehyde as a substrate instead of D-glyceraldehyde, L-DTP was synthesized.

We also found that D-DTP- and L-DTPsynthesizing activities existed in the cell-free extracts of many other microorganisms, including bacteria, actinomycetes, yeasts, and molds.

Recent evidence ${ }^{3 \sim 7)}$ has established that DDTP (1) is a direct precursor in the biosynthesis of the thiazole ring of thiamine in Escherichia coli. D-DTP has been enzymatically prepared from 1-deoxy-D-xylitol by sheep liver L-iditol dehydrogenase, ${ }^{8)}$ isolated from the culture broth of Streptomyces hygroscopicus, ${ }^{9,10)}$ and has also been chemically synthesized. ${ }^{5}$ L-DTP has been enzymatically prepared from 1-deoxy-L-xylitol by pigeon liver Lthreo-pentulose reductase. ${ }^{8}$ However, enzymatic formation of D-DTP and L-DTP by acyloin-type condensation has not previously been reported.

The present paper deals with the enzymatic formation of D-DTP and L-DTP and with the distribution of D-DTP- and L-DTPsynthesizing enzyme activities in microorganisms.

\section{Isolation and identification of $\mathrm{D}-D T P(\mathbf{1})$}

When D-glyceraldehyde was incubated with pyruvate, DL-acetoin or methylacetoin in the presence of a partially purified enzyme preparation of the mutant BG2532, a spot of a newly formed substance ( $R f 0.59$, solvent $\mathrm{B}$ ) was detected by PC, as shown in Fig. 1. The product (compound 1) was purified and isolated as crystals from the reaction mixture. 


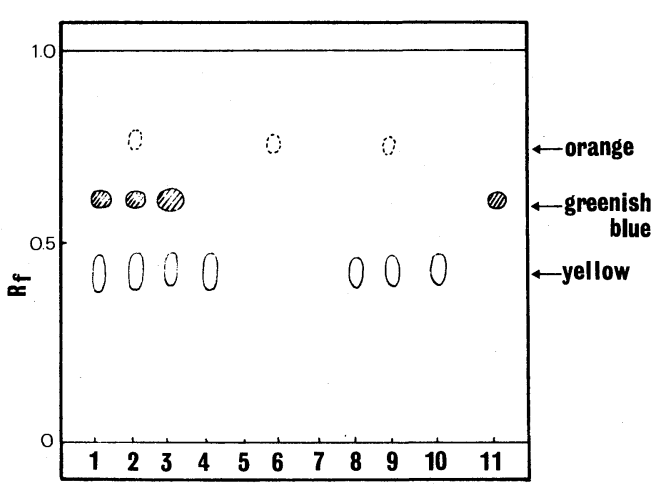

FIG. 1. Paper Chromatography of the Product Formed by a Partially Purified Enzyme Preparation of the Mutant BG2532.

Reaction mixtures $(1 \mathrm{ml})$ contained $40 \mu \mathrm{mol}$ Tris- $\mathrm{HCl}$ buffer (pH 8.0), $5 \mu \mathrm{mol} \mathrm{MgCl}_{2}, 0.5 \mu \mathrm{mol}$ TPP, $2 \mu \mathrm{mol}$ EDTA, $100 \mu \mathrm{mol}$ each of substrates, and a partially purified enzyme preparation of the mutant BG2532, which were incubated at $37^{\circ} \mathrm{C}$ overnight. The reaction was stopped by heating at $80^{\circ} \mathrm{C}$ for $3 \mathrm{~min}$. After centrifugation, the supernatants were subjected to $\mathrm{PC}$ with solvent $\mathrm{A}$. The papers were sprayed with vanillin-perchloric acid reagent and heated at $120^{\circ} \mathrm{C}$ for $5 \mathrm{~min}$. (1), D-glyceraldehyde+sodium pyruvate; (2), D-glyceraldehyde + DLacetoin; (3), D-glyceraldehyde + methylacetoin; (4), Dglyceraldehyde; (5), sodium pyruvate; (6), DL-acetoin; (7), methylacetoin; (8), (1) minus enzyme; (9), (2) minus enzyme; (10), (3) minus enzyme; (11), purified D-DTP preparation.

Elemental analysis of 1 required a molecular formula of $\mathrm{C}_{5} \mathrm{H}_{10} \mathrm{O}_{4}$. The PMR spectrum of 1 in deuterium oxide showed three methyl singlets (total $3 \mathrm{H}$ ) at $\delta 1.64,1.69$ and 2.50 in the ratios $6: 20: 72$, which suggests that 1 had one $\mathrm{C}$-methyl group and existed as a mixture of the open chain ketone $(\delta 2.50)$ and the anomers of the cyclic form ( $\delta 1.64$ and 1.69). The PMR spectrum of the acetyl derivative (2) showed that 2 had four methyl groups at the $\mathrm{CH}_{3} \mathrm{CO}$ region $(\delta 2.03 \sim 2.20)$. The mass spectrum of 2 showed ions at $m / z 260$ and 261, which might correspond to the molecular ion $\mathrm{M}^{+}$and $\mathrm{M}^{+}+1$, respectively.

From these data, 1 was assumed to be a 1deoxy-pentulose.

Comparison of specific rotations of $\mathbf{1}$ and $\mathbf{2}$ with those of known 1-deoxy-pentuloses and
TABle I. Comparison of SPeCific Rotations of 1-DeOXY-PENTUloses 1 AND 5, AND Their Triacetate Derivatives with Those of KNOWN 1-DEOXY-PENTULOSES AND Their Triacetate Derivatives

\begin{tabular}{|c|c|c|}
\hline Compound & {$[\alpha]_{D}\left({ }^{\circ}\right)$} & Solvent \\
\hline \multirow{2}{*}{$\begin{array}{l}\text { 1-Deoxy-pentulose } 1 \\
\text { triacetate } 2\end{array}$} & +33.6 & $\mathrm{H}_{2} \mathrm{O}$ \\
\hline & +44 & $\mathrm{CHCl}_{3}$ \\
\hline \multirow{2}{*}{$\begin{array}{l}\text { 1-Deoxy-pentulose } 5 \\
\text { triacetate } 6\end{array}$} & -44 & $\mathrm{H}_{2} \mathrm{O}$ \\
\hline & -43 & $\mathrm{CHCl}_{3}$ \\
\hline \multicolumn{3}{|l|}{ 1-Deoxy-pentulose } \\
\hline D-threo & $+34,^{a}+46^{b}$ & $\mathrm{H}_{2} \mathrm{O}$ \\
\hline D-threo, triacetate & $+52^{c}$ & $\mathrm{CHCl}_{3}$ \\
\hline $\mathrm{L}-$ threo & - & \\
\hline L-threo, triacetate & $-53^{d}$ & $\mathrm{CHCl}_{3}$ \\
\hline D-erythro & $-30,^{a}-37^{e}$ & $\mathrm{H}_{2} \mathrm{O}$ \\
\hline D-erythro, triacetate & $-8^{e}$ & $\mathrm{CHCl}_{3}$ \\
\hline L-erythro & - & \\
\hline L-erythro, triacetate & - & \\
\hline
\end{tabular}

a Data from ref. 5.

$b$ Data from ref. 9 .

c Data from ref. 10.

d Data from ref. 11.

e Data from ref. 12 .

their acetyl derivatives, ${ }^{5,9 \sim 12)}$ as shown in Table I, suggests that the configuration of 1 and $\mathbf{2}$ is $\mathbf{D}$-threo.

The configuration of $\mathbf{1}$ was further characterized by reduction and acetylation to the corresponding 1-deoxy-pentitol acetates. The products 3 and 4 were identified as tetra- $O$ acetyl-1-deoxy-D-lyxitol*1 and tetra- $O$-acetyl1-deoxy-D-xylitol, respectively, by comparing the physical data of these compounds with those of known 1-deoxy-pentitol tetraacetates $^{10,13 \sim 16)}$ (Table II). These experiments settle the configuration of $\mathbf{1}$ as D-threo.

Therefore, the product (1) of the enzyme reaction was determined to be 1-deoxy-Dthreo-pentulose (D-DTP) and 2 was to be tri$O$-acetyl-1-deoxy-D-threo-pentulose (Fig. 2).

\section{Isolation and identification of $\mathrm{L}-\mathrm{DTP}$ (5)}

When L-glyceraldehyde was incubated with pyruvate (or DL-acetoin or methylacetoin) by a similar method in D-DTP formation, a prod-

\footnotetext{
*1 Systematic name: Tetra- $O$-acetyl-5-deoxy-D-arabinitol.
} 
Table II. Comparison of Physical Data of COMPOUNDS 3 and 4 With ThOSE OF KNown 1-Deoxy-Pentitol TetraAcetates

\begin{tabular}{lclc}
\hline $\begin{array}{c}\text { Parent } \\
\text { 1-deoxy- } \\
\text { pentulose }\end{array}$ & $\begin{array}{c}\text { 1-Deoxy-pentitol } \\
\text { tetraacetate }\end{array}$ & $\operatorname{mp}\left({ }^{\circ} \mathrm{C}\right)$ & {$[\alpha]_{\mathrm{D}}\left({ }^{\circ}\right)$} \\
\hline Compound 1 & $\begin{array}{c}\text { Compound 3 } \\
\text { Compound 4 }\end{array}$ & $\begin{array}{l}\text { Amorphous } \\
\text { Syrup }\end{array}$ & $\begin{array}{c}+46.3 \\
+9.2\end{array}$ \\
\hline & D-lyxo & $\begin{array}{l}52 \sim 54 \\
58 \sim 59\end{array}$ & $\begin{array}{c}+47^{a} \\
+46.1^{b} \\
\text { D-threo }\end{array}$ \\
& D-xylo & $\begin{array}{l}\text { Syrup } \\
62 \sim 63\end{array}$ & $+10.4^{c}$ \\
\hline & L-arabino & $\begin{array}{l}115 \\
113 \sim 114^{e}\end{array}$ & $-26.37^{d}$ \\
& L-ribo & - & - \\
\hline
\end{tabular}

a Data from ref. 10.

$b$ Data from ref. 13.

c Data from ref. 14.

d Data from ref. 15.

e Data from ref. 16 .

\begin{tabular}{|c|c|c|}
\hline $\begin{array}{c}\mathrm{CH}_{3} \\
\mathrm{C}=0 \\
\mathrm{ROCH} \\
\mathrm{ROCOR} \\
\mathrm{HCH} \mathrm{CH}_{2} \mathrm{OR}\end{array}$ & $\begin{array}{c}\mathrm{CH}_{3} \\
\mathrm{AcOCH} \\
\mathrm{AcOC} \mathrm{CH} \\
\mathrm{HC} \mathrm{CAC} \\
{ }_{\mathrm{CH}} \mathrm{H}_{2} \mathrm{OAC}\end{array}$ & 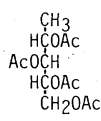 \\
\hline 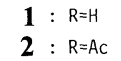 & 3 & 4 \\
\hline $\begin{array}{c}\mathrm{CH}_{3} \\
\mathrm{C}=0 \\
\mathrm{HCOR} \\
\mathrm{ROCH} \\
\stackrel{\mathrm{C}}{\mathrm{CH}} \mathrm{H}_{2} \mathrm{OR}\end{array}$ & $\begin{array}{c}\mathrm{CH}_{3} \\
\mathrm{HC} O \mathrm{OAC} \\
\mathrm{HCOAC} \\
\mathrm{ACOCO \textrm {CH }} \\
\stackrel{\mathrm{C}}{\mathrm{C}} \mathrm{H}_{2} \mathrm{OAC}\end{array}$ & $\begin{array}{c}\mathrm{CH}_{3} \\
\mathrm{ACOC} \mathrm{C}^{3} \\
\mathrm{HC} \mathrm{CAC} \\
\mathrm{ACOC} \mathrm{C} \\
\stackrel{\mathrm{C}}{\mathrm{C}} \mathrm{H}_{2} \mathrm{OAC}\end{array}$ \\
\hline $\begin{array}{l}5: R=H \\
\text { 6: }: R=A C\end{array}$ & 7 & 8 \\
\hline
\end{tabular}

FIG. 2. Structures of 1-Deoxy-D-threo-pentulose (1), 1Deoxy-L-threo-pentulose (5) and Their Derivatives.

uct, which showed the same $R f$ values and color reactions as D-DTP on PC, was formed.

The reaction product (5) from $L^{-}$ glyceraldehyde and DL-acetoin by the enzyme preparation of the mutant BG2532 was purified and isolated as crystals from the reaction mixture. Elemental analysis of 5 required a molecular formula of $\mathrm{C}_{5} \mathrm{H}_{10} \mathrm{O}_{4}$. The $\mathrm{PMR}$ spectra of 5 and its acetyl derivative (6) were identical with those of $\mathbf{1}$ and 2 , respectively. The mass spectrum of $\mathbf{6}$ showed ions at $\mathrm{m} / \mathrm{z}$ 260 and 261, which might correspond to the
Table III. Comparison of Physical Data of Compounds 7 and 8 WITH Those of Known 1-Deoxy-Pentitol TetraAcetates

\begin{tabular}{cccc}
\hline $\begin{array}{c}\text { Parent } \\
\text { 1-deoxy- } \\
\text { pentulose }\end{array}$ & $\begin{array}{c}\text { 1-Deoxy-pentitol } \\
\text { tetraacetate }\end{array}$ & $\mathrm{mp}\left({ }^{\circ} \mathrm{C}\right)$ & {$[\alpha]_{\mathrm{D}}\left({ }^{\circ} \mathrm{C}\right)$} \\
\hline Compound 5 & $\begin{array}{c}\text { Compound 7 } \\
\text { Compound } 8\end{array}$ & $\begin{array}{c}\text { Syrup } \\
\text { Syrup }\end{array}$ & $\begin{array}{c}-41 \\
-8.8\end{array}$ \\
\hline \multirow{2}{*}{ L-threo } & L-lyxo & $57 \sim 58$ & $-47^{a}$ \\
& L-xylo & Syrup & $-2^{b}$ \\
\hline & D-arabino & $115 \sim 116$ & $+27.30^{c}$ \\
D-erythro & D-ribo & - & - \\
\hline
\end{tabular}

a Data from ref. 17.

$b$ Data from ref. 18

c Data from ref. 15.

molecular ion $\mathrm{M}^{+}$and $\mathbf{M}^{+}+1$, respectively. These data suggested that 5 was a 1-deoxypentulose.

The comparison of specific rotations of $\mathbf{5}$ and 6 with those of known 1-deoxy-pentuloses and their acetyl derivatives, ${ }^{5,9 \sim 12)}$ as shown in Table I, suggests that the configuration of 5 and 6 is L-threo.

The configuration of 5 was further characterized by reduction and acetylation by the same method as for the preparation of $\mathbf{3}$ and 4. From the results of elemental analyses and PMR spectra together with comparing the specific rotations of these compounds with those of known 1-deoxy-pentitol tetraacetates $^{15,17,18)}$ (Table III), the reduction products 7 and 8 were identified as tetra- $O$ acetyl-1-deoxy-L-lyxitol ${ }^{* 2}$ and tetra- $O$-acetyl1-deoxy-L-xylitol, respectively. These experiments settle the configuration of 5 as L-threo.

Therefore, the product (5) of the enzyme reaction was determined to be 1-deoxy-Lthreo-pentulose (L-DTP), and the acetyl derivative 6 to be tri-O-acetyl-1-deoxy-L-threopentulose (Fig. 2).

\section{Mechanism of the enzyme reaction}

In the reaction mixture containing DLacetoin and D-glyceraldehyde, acetaldehyde 


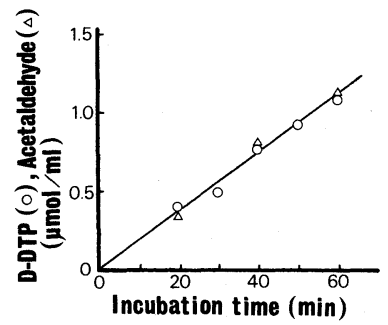

FIG. 3. Effect of Incubation Time on D-DTP and Acetaldehyde Formation from D-glyceraldehyde and DLAcetoin.

Reaction conditions are the same as those in Fig. 1. The reaction was terminated by cooling in an ice bath, and DDTP and acetaldehyde formed were determined by the assay methods as described in EXPERIMENTAL.

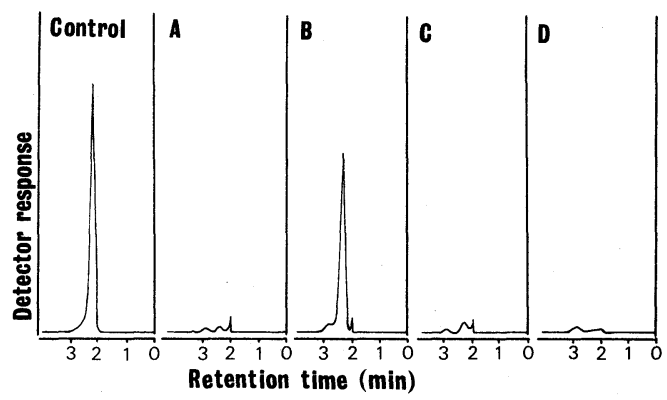

Fig. 4. Gas Chromatograms of the Product of the Enzyme Reaction between D-Glyceraldehyde and Methylacetoin.

Experimental conditions are described in the text. Control, authentic acetone; A, D-glyceraldehyde and methylacetoin $(0 \mathrm{hr}) ; \mathrm{B}, \mathrm{D}$-glyceraldehyde and methylacetoin $(2 \mathrm{hr})$; $\mathrm{C}$, methylacetoin (2 hr); D, D-glyceraldehyde ( $2 \mathrm{hr}$ ).

was detected as another reaction product associated with D-DTP (Fig. 3). DL-Acetoin could be replaced by pyruvate or methylacetoin for D-DTP and L-DTP formation. When methylacetoin was used, acetone was detected by gas chromatography as another reaction product associated with D-DTP (Fig. 4). These results, together with our previous results on 1-deoxy-D-altro-heptulose phosphate formation, ${ }^{2)}$ suggest that D-DTP- and LDTP-synthesizing reactions by combinations of D- or L-glyceraldehyde with pyruvate, DLacetoin, or methylacetoin proceed according to the following formulae:

$$
\text { Pyruvate }+ \text { D-Glyceraldehyde } \longrightarrow
$$

$$
\begin{gathered}
\mathrm{CO}_{2}+\mathrm{D}-\mathrm{DTP} \\
\text { DL-Acetoin }+\mathrm{D}-\text { Glyceraldehyde } \longrightarrow \\
\text { Acetaldehyde }+ \text { D-DTP } \\
\text { Methylacetoin }+ \text { D-Glyceraldehyde } \longrightarrow \\
\text { Acetone }+ \text { D-DTP } \\
\text { Pyruvate }+ \text { L-Glyceraldehyde } \longrightarrow \\
\mathrm{CO}_{2}+\text { L-DTP }
\end{gathered}
$$$$
\text { DL-Acetoin + L-Glyceraldehyde } \longrightarrow
$$$$
\text { Acetaldehyde + L-DTP }
$$$$
\text { Methylacetoin }+ \text { L-Glyceraldehyde } \longrightarrow
$$

$$
\text { Acetone }+ \text { L-DTP }
$$

The products of the condensation reaction are 1-deoxy-pentuloses with trans configuration of hydroxyls at carbons 3 and 4 .

The apoenzyme preparation, obtained by gel filtration as described in EXPERIMENTAL, absolutely required $\mathrm{Mg}^{2+}$ and TPP, as shown in Table IV.

Distribution of D-DTP and L-DTP synthesizing enzyme activities in microorganisms

From the experiments of the incorporation of deuterated carbohydrates and related compounds into thiamine in $E$. coli, White ${ }^{3,4)}$ postulated that 1-deoxy-pentulose phosphate, probably produced by an acyloin condensation between D-glyceraldehyde 3-phosphate and pyruvate, might be a precursor of the thiazole moiety of thiamine. More recently, Therisod et al. ${ }^{5)}$ and David et al. ${ }^{6,7)}$ found that the carbon chain of D-DTP is the specific precursor of the five carbon chain of the thiazole moiety of the thiamine molecule. However, neither the presence of D-DTP (phosphate) nor the presence of its synthesizing enzyme in $E$. coli cells has yet been described.

On the other hand, White and Spenser ${ }^{19,20)}$ found that in Saccharomyces cerevisiae a fivecarbon unit of thiazole might be derived from a phosphoketopentose (D-ribulose 5-phosphate or D-xylulose 5-phosphate) but not from 
TABLE IV. COFACTORS REQUIRED FOR D-DTP Formation BY B. pumilus MUTANT BG2532 AND $E$. coli IFO 13168 APOENZYME

PREPARATIONS

A complete reaction mixture contained $40 \mu \mathrm{mol}$ Tris$\mathrm{HCl}$ buffer ( $\mathrm{pH} \mathrm{8.0),} 5 \mu \mathrm{mol} \mathrm{MgCl}_{2}, 0.5 \mu \mathrm{mol}$ TPP, 2 $\mu \mathrm{mol}$ EDTA, $50 \mu \mathrm{mol}$ each of substrates, and $0.2 \mathrm{ml}$ of apoenzyme solution in a total volume of $1 \mathrm{ml}$, which was incubated at $37^{\circ} \mathrm{C}$ for $16 \mathrm{hr}$. The reaction was stopped by heating at $80^{\circ} \mathrm{C}$ for $3 \mathrm{~min}$. After centrifugation, the supernatant was subjected to TLC. Method for determination of D-DTP is described in EXPERIMENTAL. As substrate other than D-glyceraldehyde, sodium pyruvate was used in Expt. (1) and (2), DL-acetoin in Expt. (3) and methylacetoin in Expt. (4). Apoenzyme preparations from B. pumilus mutant BG2532 and E. coli IFO 13168 were used in Expt. (1) (3) and in Expt. (4), respectively.

\begin{tabular}{ccc}
\hline Expt. & Component omitted & $\begin{array}{c}\text { D-DTP formed } \\
(\mathrm{mg} / \mathrm{ml})\end{array}$ \\
\hline \multirow{2}{*}{$(1)$} & Complete & 1.92 \\
& $-\mathrm{TPP}$ & 0 \\
& $-\mathrm{MgCl}_{2}$ & 0 \\
& - enzyme & 0 \\
\hline (2) & Complete & 3.28 \\
& - TPP & 0 \\
& $-\mathrm{MgCl}_{2}$ & 0 \\
& - enzyme & 0 \\
\hline (3) & Complete & 8.56 \\
& $-\mathrm{TPP}^{2}$ & 0.54 \\
& $-\mathrm{MgCl}_{2}$ & 0.46 \\
& - enzyme & 0 \\
\hline \multirow{2}{*}{$(4)$} & Complete & 1.22 \\
& - TPP & 0.08 \\
& $-\mathrm{MgCl}_{2}$ & 0 \\
& - enzyme & 0 \\
\hline
\end{tabular}

D-DTP (phosphate). The participation of the phosphoketopentose in thiamine biosynthesis was deduced from data on the mode of incorporation of ${ }^{14} \mathrm{C}$-labelled hexoses.

D-DTP-synthesizing enzyme(s) having been detected in the transketolase mutant of $B$. pumilus as described above, we thought that it played an important role in the biosynthesis of thiamine. Therefore, we examined the distribution of this enzyme activity in various microorganisms.

As Table $\mathrm{V}$ shows, not only bacteria but also actinomycetes, yeasts, and molds had the ability to catalyze the acyloin-type condensation between D-glyceraldehyde and pyruvate to form D-DTP. When L-glyceraldehyde was used as a substrate instead of D-glyceraldehyde, these cell-free extracts catalyzed the formation of L-DTP.

D-DTP and L-DTP-synthesizing enzyme activities were detected in the soluble fractions of cells of all strains of bacteria except for the acetic acid bacteria Acetobacter and Gluconobacter, in which the activities were detected in the insoluble fractions. Relatively weak activities were found only in the insoluble fractions of yeast strains, which suggests that these enzymes are also membranebound. The enzyme activities were detected in both the soluble and insoluble fractions in molds (Table V).

Reaction products from the cell-free extracts of E. coli IFO 13168 (strain B) and B. subtilis IFO 13719 (strain Marburg) were purified and isolated by the same method as that of the $B$. pumilus mutant. The specific rotations of those for $E$. coli and $B$. subtilis were $[\alpha]_{\mathrm{D}}+26.2^{\circ}(c=$ $\left.1, \mathrm{H}_{2} \mathrm{O}\right)$ and $[\alpha]_{\mathrm{D}}+30.1^{\circ}\left(c=1, \mathrm{H}_{2} \mathrm{O}\right)$, respectively. $R f$ values on PC and TLC were identical with those of D-DTP. Furthermore, the reaction products by a yeast, Saccharomyces cerevisiae, and a mold, Aspergillus oryzae, showed the same color reactions and $R f$ values on PC and TLC as those of D-DTP (data not shown).

The enzyme solution prepared from $E$. coli also showed absolute requirements for $\mathbf{M g}^{2+}$ and TPP as cofactors, as shown in Table IV.

\section{DISCUSSION}

1-Deoxy-threo-pentulose synthesizing enzyme(s) requires TPP and $\mathrm{Mg}^{2+}$ as cofactors, suggesting that hydroxyethyl-TPP might participate in the enzyme reaction as an intermediate. The reaction mechanism was presumed to be analogous to that of 1-deoxy-Daltro-heptulose phosphate synthase, and therefore, D-DTP and L-DTP synthesizing enzyme(s) can also be regarded as a carboligase which is known to cause the condensation of acetaldehyde with another acetal- 
TABle V. D-DTP AND L-DTP Synthesis By CELl-free EXTRACTS OF VARIOUS MicroorganisMS

\begin{tabular}{|c|c|c|c|c|c|}
\hline Microorganism & IFO No. & Medium & $\begin{array}{l}\text { Protein }^{a} \\
(\mathrm{mg} / \mathrm{ml})\end{array}$ & $\begin{array}{l}\text { D-DTP } \\
(\mathrm{mg} / \mathrm{ml})^{c}\end{array}$ & $\begin{array}{c}\text { Formation of } \\
\text { L-DTP }\end{array}$ \\
\hline \multicolumn{6}{|l|}{ (Bacteria) } \\
\hline Acetobacter aceti & 3281 & $\mathrm{E}$ & 1.0 & Trace & $-f$ \\
\hline Acetobacter aceti & 3281 & $\mathrm{E}$ & $\mathrm{ppt}^{b}$ & 1.24 & + \\
\hline Acinetobacter calcoaceticus & 12552 & B & 1.4 & 0.32 & + \\
\hline Aerococcus viridans & 12317 & $\mathrm{C}$ & 2.4 & 0.12 & + \\
\hline Aeromonas hydrophila & 3820 & B & 1.6 & 0.65 & + \\
\hline Alcaligenes faecalis & 13111 & B & 2.8 & 0.98 & + \\
\hline Agrobacterium tumefaciens & 3058 & B & 2.5 & 0.43 & + \\
\hline Arthrobacter globiformis & 12137 & B & 1.5 & 0.29 & + \\
\hline Azotobacter chroococcum & 12994 & $\mathrm{D}$ & 1.2 & 1.28 & + \\
\hline Bacillus pumilus & 12089 & A & 1.2 & 1.18 & + \\
\hline Bacillus pumilus BG2532 & & A & 2.6 & 1.66 & + \\
\hline Bacillus subtilis & 13719 & A & 1.2 & 0.68 & + \\
\hline Brevibacterium lines & 12141 & $\mathrm{~B}$ & 0.9 & 0.37 & + \\
\hline Corynebacterium michiganense & 12471 & B & 1.2 & 0.47 & + \\
\hline Cytophaga heparina & 12017 & B & 1.5 & 1.08 & + \\
\hline Erwinia carotovora & 3380 & B & 0.7 & 0.51 & + \\
\hline Escherichia coli & 13168 & $\mathrm{C}$ & 1.8 & 1.22 & + \\
\hline Flavobacterium capsulatum & 12533 & B & 1.1 & 0.86 & + \\
\hline Gluconobacter oxydans & 3189 & $\mathrm{E}$ & 0.4 & $-d$ & - \\
\hline Gluconobacter oxydans & 3189 & $\mathrm{E}$ & ppt & 0.09 & + \\
\hline Klebsiella pneumoniae & 3317 & B & 1.6 & 2.45 & + \\
\hline Microbacterium lacticum & 14135 & B & 1.5 & 0.59 & + \\
\hline Micrococcus luteus & 3333 & $\mathrm{C}$ & 1.7 & 0.52 & + \\
\hline Proteus vulgaris & 3851 & B & 2.1 & 0.65 & + \\
\hline Pseudomonas aeruginosa & 12689 & B & 2.7 & 1.25 & + \\
\hline Rhizobium leguminosarum & 14168 & $\mathrm{D}$ & 1.4 & 1.25 & + \\
\hline Salmonella typhimurium & 13245 & B & 2.0 & 0.98 & + \\
\hline Serratia marcescens & 3046 & B & 2.0 & 1.25 & + \\
\hline Staphylococcus aureus & 3060 & B & 1.2 & 0.41 & + \\
\hline $\begin{array}{l}\text { Xanthomonas citri } \\
\text { (Actinomycetes) }\end{array}$ & 3835 & B & 2.1 & 0.58 & + \\
\hline Actinoplanes missouriensis & 13243 & $\mathrm{~F}$ & 1.3 & 0.86 & + \\
\hline Micromonospora coerulea & 13504 & $\mathrm{~F}$ & 1.4 & 0.69 & + \\
\hline Micropolyspora brevicatena & 12119 & $\mathrm{~F}$ & 0.8 & 0.41 & + \\
\hline Nocardia erythropolis & 12682 & $\mathrm{~F}$ & 1.8 & 0.82 & + \\
\hline $\begin{array}{l}\text { Streptomyces griseus } \\
\quad \text { (Yeasts) }\end{array}$ & 3430 & $\mathrm{~F}$ & 0.8 & 1.54 & + \\
\hline Candida albicans & 1594 & $\dot{G}$ & ppt & Trace & Trace \\
\hline Hansenula anomala & 0122 & $\mathrm{G}$ & ppt & 0.15 & Trace \\
\hline Pichia farinosa & 1163 & G & ppt & 0.10 & Trace \\
\hline Rhodotorula glutinis & 0667 & G & ppt & 0.09 & Trace \\
\hline $\begin{array}{l}\text { Saccharomyces cerevisiae } \\
\quad \text { (Molds) }\end{array}$ & 2043 & G & ppt & 0.09 & Trace \\
\hline Aspergillus oryzae & 30104 & $\mathrm{H}$ & 0.8 & 0.10 & Trace \\
\hline Aspergillus oryzae & 30104 & $\mathrm{H}$ & $\mathrm{ppt}$ & 0.16 & Trace \\
\hline Monascus ruber & 9203 & $\mathrm{H}$ & 1.0 & 0.10 & Trace \\
\hline Monascus ruber & 9203 & $\mathrm{H}$ & ppt & 0.09 & Trace \\
\hline Mucor hiemalis $\mathrm{f}$. hiemalis & 9404 & $\mathrm{H}$ & 0.8 & 0.09 & Trace \\
\hline Mucor hiemalis $\mathrm{f}$. hiemalis & 9404 & $\mathrm{H}$ & $\mathrm{ppt}$ & 0.19 & Trace \\
\hline Penicillium funiculosum & 6345 & $\mathrm{H}$ & 1.0 & 0.10 & Trace \\
\hline Penicillium funiculosum & 6345 & $\mathrm{H}$ & ppt & 0.11 & Trace \\
\hline
\end{tabular}

a Soluble fractions were added at the indicated concentration of protein to the reaction mixtures, which were 
dehyde or other aldehydes to form acyloin compounds. Many acyloin-type condensation are known to be catalyzed by the enzymes $\alpha$ acetolactate synthase, ${ }^{22}$ pyruvate oxidase, ${ }^{23)}$ pyruvate dehydrogenase of the pyruvate dehydrogenase system, ${ }^{24)}$ pyruvate decarboxylase ${ }^{25)} \alpha$-ketoglutarate dehydrogenase of the $\alpha$-ketoglutarate dehydrogenase system, ${ }^{26}$ ) acetoin dehydrogenase, ${ }^{27)}$ etc. However, 1deoxy-ketose formation has not yet been reported by these enzymes.

When glycoaldehyde or D-erythrose or Dthreose was used as a substrate instead of D- or L-glyceraldehyde, 1-deoxy-erythrulose, 1deoxy-D-fructose or 1-deoxy-D-sorbose was also formed as a reaction product. ${ }^{28)}$ 1-Deoxyketoses have been chemically synthesized by several routes from aldoses or their derivatives by reaction with one carbon compound or one carbon donor. The reaction sequences involve several steps and the overall yields are relatively low. Therefore, the enzyme reaction described here can be used as a convenient method for the preparation of 1-deoxyketoses, in a one-step synthesis by an enzymatic method with good yield.

In view of the catalytic properties of 1deoxy-ketose-synthesizing enzyme(s), it appears appropriate to designate the enzyme acetaldehyde-transferase (EC 2.2.1) according to the enzyme nomenclature recommended by the Nomenclature Committee of the International Union of Biochemistry (1978). ${ }^{29)}$ However, further investigation must be performed with purified enzyme preparations to characterize the enzyme(s).
The findings described in this report may provide some clues to elucidate the biosynthetic pathway of thiamine in microorganisms. White and Spenser ${ }^{19,20)}$ have proposed a biosynthetic pathway of thiamine in yeast including pentulose phosphate as the precursor. However, the present study suggests that DDTP might be a precursor of thiamine in yeasts and molds as well as in bacteria. In eucaryotes thiamine might be synthesized partly through the same metabolic pathway as in procaryotes.

Very weak enzyme activity for D-DTP phosphate formation from D-glyceraldehyde 3phosphate and pyruvate could be detected in cell-free extracts of only a few bacterial strains. Furthermore, the presence of D-DTP in the cells of E. coli was confirmed but not that of its phosphorylated derivative (data not shown). These preliminary experiments suggest that the precursor of the thiazole ring of thiamine may be D-DTP, not its phosphorylated derivative as suggested by White. ${ }^{3)}$

As L-glyceraldehyde and methylacetoin have not yet been isolated from biological material, L-DTP cannot be considered to be formed by this enzyme reaction in vivo, and methylacetoin cannot be considered an in vivo substrate for D-DTP formation.

\section{EXPERIMENTAL}

\section{General methods.}

Microorganisms and culture conditions. The mutant BG2532 of B. pumilus IFO 12089, ${ }^{1)}$ which is leaky in transketolase activity, was mainly used. It was cultured in medium A, which contained $2 \%$ sodium maleate $1 \%$ yeast

incubated at $37^{\circ} \mathrm{C}$ for $16 \mathrm{hr}$.

$b$ Insoluble fractions of the disrupted cells which were suspended in the same volume of buffer A were used.

c A reaction mixture containing $100 \mu \mathrm{mol}$ of L-glyceraldehyde, $100 \mu \mathrm{mol}$ of sodium pyruvate, $80 \mu \mathrm{mol}$ of Tris- $\mathrm{HCl}$ buffer ( $\mathrm{pH} 8.0$ ), $5 \mu \mathrm{mol}$ of $\mathrm{MgCl}_{2}, 0.5 \mu \mathrm{mol}$ of TPP, $2 \mu \mathrm{mol}$ of EDTA, and $0.2 \mathrm{ml}$ of enzyme preparation in a total volume of $1.0 \mathrm{ml}$ was incubated at $37^{\circ} \mathrm{C}$ for $20 \mathrm{hr}$. Method for determination of D-DTP is described in EXPERIMENTAL.

d Not detected.

$e \quad$ L-DTP formed was detected by PC as follows: A reaction mixture containing the same composition as in c) except for employment of L-glyceraldehyde as a substrate instead of D-glyceraldehyde, was incubated at $37^{\circ} \mathrm{C}$ for $20 \mathrm{hr}$. After incubation, the reaction mixture was heated at $80^{\circ} \mathrm{C}$ for $3 \mathrm{~min}$ and centrifuged at $3000 \mathrm{rpm}$ for 10 min. An aliquot $\left(10 \sim 20 \mu\right.$ l) of the resulting supernatant was applied on a filter paper. Vanillin-perchloric acid ${ }^{21)}$ was sprayed on the paper and heated at $120^{\circ} \mathrm{C}$ for $5 \mathrm{~min}$.

$f$ The signs plus and minus represent positive and negative enzyme activities, respectively, which were examined by PC. 
extract, and $0.5 \%$ ammonium sulfate, $\mathrm{pH} 7.0$. Other wildtype strains of bacteria, actinomycetes, yeasts, and molds used were obtained from the IFO (Institute for Fermentation, Osaka) culture collection, and were cultured in the following media: medium B, $2 \%$ D-glucose, $0.05 \%$ peptone, $0.02 \%$ yeast extract, and $0.02 \% \mathrm{NaCl}, \mathrm{pH}$ 7.0 ; medium C, $2 \%$ D-glucose, $0.5 \%$ peptone, $0.2 \%$ yeast extract, and $0.2 \% \mathrm{NaCl}, \mathrm{pH} 7.0$; medium $\mathrm{D}, 1.5 \%$ mannitol, $0.1 \%$ yeast extract, $0.02 \% \quad \mathrm{~K}_{2} \mathrm{HPO}_{4}, \quad 0.02 \%$ $\mathrm{MgSO}_{4} \cdot 7 \mathrm{H}_{2} \mathrm{O}, 0.02 \% \mathrm{NaCl}$, and $0.01 \% \mathrm{CaSO}_{4} \cdot 2 \mathrm{H}_{2} \mathrm{O}$, pH 7.2; medium E, $1 \%$ glycerol and $0.5 \%$ yeast extract, pH 6.0 ; medium F, $1 \%$ maltose, $0.1 \%$ yeast extract, $0.1 \%$ beef extract, and NZ Amine, pH 7.3; medium G, 2\% D-glucose, $0.2 \%$ yeast extract, $0.1 \%$ ammonium sulfate, $0.05 \%$ $\mathrm{KH}_{2} \mathrm{PO}_{4}, 0.05 \% \mathrm{MgSO}_{4} \cdot 7 \mathrm{H}_{2} \mathrm{O}$, and $0.03 \% \mathrm{CaCl}_{2} \cdot 2 \mathrm{H}_{2} \mathrm{O}$, pH 5.0; medium $\mathrm{H}, 0.2 \%$ D-glucose, $2 \%$ malt extract, and $0.1 \%$ peptone, $\mathrm{pH} 6.0$.

Cell-free enzyme preparations. Cells were harvested by centrifugation, washed with $0.01 \mathrm{M}$ Tris- $\mathrm{HCl}$ buffer $(\mathrm{pH}$ 7.5) containing $5 \mathrm{~mm} \mathrm{MgCl}, 1 \mathrm{mM}$ TPP, $2 \mathrm{mM}$ EDTA, $0.1 \mathrm{~mm}$ phenylmethylsulfonyl fluoride, and $5 \mathrm{~mm} 2$-mercaptoethanol (buffer A), and suspended in the same buffer.

Cells of bacterial, actinomycete, and mold strains were then disrupted with an ultrasonic oscillator, while yeast cells were treated with Zymolyase 5000 (20 units $/ \mathrm{ml})$ at $30^{\circ} \mathrm{C}$ for $1 \mathrm{hr}$ before disruption in the same way. After centrifugation at $13,000 \times g$ for $10 \mathrm{~min}$, the supernatants were used as the soluble fractions and the precipitates as insoluble fractions.

Partial purification of $\mathrm{D}-\mathrm{DTP}$ and L-DTP synthesizing enzyme (s) from mutant strain BG2532. The soluble fraction of the mutant BG2532 was obtained from cells cultured in medium A. To the soluble fraction was added $1 \%$ protamine sulfate solution $(7: 1)$. After $15 \mathrm{~min}$, the precipitate was removed by centrifugation at $13,000 \times g$ for $20 \mathrm{~min}$. Solid ammonium sulfate was added to the supernatant to $30 \%$ saturation. After $15 \mathrm{~min}$, the precipitate formed was separated by centrifugation and discarded. Solid ammonium sulfate was added to the supernatant to $60 \%$ saturation. The precipitate formed was collected by centrifugation and dissolved in buffer A. The solution was dialyzed against the same buffer, and then used as the partially purified enzyme preparation.

Partial purification of D-DTP synthesizing enzyme from B. subtilis IFO 13719 and E. coli IFO 13168. Strains of $B$. subtilis and $E$. coli were cultured in the chemically defined medium of Tomlinson ${ }^{31)}$ and medium $\mathrm{C}$, respectively. Soluble fractions were obtained from the cells by the method described above. Solid ammonium sulfate was added to $80 \%$ saturation to the soluble fractions. The resulting precipitates were collected by centrifugation at $13,000 \times g$ for $20 \mathrm{~min}$, and were dissolved in buffer $\mathrm{A}$. The solutions were dialyzed against the same buffer, and then used as partially purified enzyme preparations.

Preparation of apoenzyme. Enzyme solution used for the examination of cofactor requirements was prepared as follows: the partially purified enzyme solution was applied to a Sephadex G-25 column $(1.0 \times 27 \mathrm{~cm})$ which had been equilibrated with $0.01 \mathrm{M}$ Tris- $\mathrm{HCl}$ buffer $(\mathrm{pH} 7.5)$ and eluted with the same buffer. The active fractions were combined and used.

Assay of D-DTP. D-DTP formed by the enzyme reaction was assayed by the method of Iwakawa et al. ${ }^{30)}$ as follows. An aliquot $(5 \sim 20 \mu \mathrm{l})$ of the supernatant was applied on a TLC plate, which was developed with solvent B and airdried. Ethylenediamine sulfate reagent was sprayed on the plate and the fluorescence intensity on the chromatogram was measured with a Shimadzu CS-910 TLC scanner.

Assay of acetaldehyde. A reaction mixture $(100 \mu \mathrm{l})$, was incubated in a microtube $(7 \times 50 \mathrm{~mm})$ with a rubber bung, and the acetaldehyde formed was determined by the method described in a previous paper. ${ }^{2)}$

Determination of protein concentration. Protein concentrations were determined by the method of Lowry et $a l .^{32)}$ with bovine serum albumin as the standard.

$P C, T L C$ and column chromatography. PC on Toyo Roshi No. 51 filter paper, TLC on silica gel plates $(20 \times 20 \mathrm{~cm}, 0.25 \mathrm{~mm}$, E. Merck), and column chromatographies with CF-11 cellulose powder (Whatman) and with silica gel 60 (70 230 mesh, E. Merck) were performed at room temperature with one of the following solvent systems (by vol.): (A) isobutanol-pyridine-acetate-water (12:6:1:4), (B) ethyl acetate-pyridine-water $(40: 11: 6)$, (C) acetone-ethyl acetate (1:1), (D) ether-petroleum ether $(2: 1)$, (E) ether-petroleum ether $(1: 1)$, (F) ethyl acetatebenzene $(1: 1)$ and $(\mathrm{G})$ ethyl acetate- $n$-hexane $(1: 2)$. As spray reagents, alkaline silver nitrate, alkaline tripenyltetrazolium chloride, vanillin-perchloric acid, ${ }^{21)}$ and orcinolferric chloride-hydrochloride were used for $\mathrm{PC}$, and 50\% sulfuric acid for TLC.

Gas chroamtography. Acetone formed by the enzyme reaction was detected by gas chromatography. The reaction mixture was adjusted to $\mathrm{pH} 1 \sim 2$ with $5 \mathrm{~N} \mathrm{HCl}$. After centrifugation, $2 \mu \mathrm{l}$ of the supernatant was injected into a Shimadzu GC-4BM gas chromatograph with a column (glass, $4 \mathrm{~m}$ ) of $25 \%$ Flexol $8 \mathrm{~N} 8$ on Chromosorb W. $\mathrm{He}$ gas was the carrier and a flame-ionization detector was the detector. The column temperature and the injector temperature were 80 and $100^{\circ} \mathrm{C}$, respectively.

Physical and chemical analyses. Melting points were uncorrected. Optical rotations were measured with a Japan Spectroscopic DIP-181 polarimeter. PMR spectra were measured with a Varian EM-390 $(90 \mathrm{MHz})$ spectrometer with tetramethylsilane as a reference. Mass spectra were measured with a JEOL JMS-01SG mass spectrometer. IR spectra were measured with a Shimadzu IR-420 spectrometer.

Chemicals. Alcohol dehydrogenase (yeast), Dglyceraldehyde, and L-glyceraldehyde were purchased from the Sigma Chemical Co. DL-Acetoin (monomer) was purchased from Wako Pure Chemical Industries, which was crystallized as the dimer before use. Methylacetoin was purchased from the Tokyo Kasei Industrial Co. 
Isolation of $\mathrm{D}-D T P(\mathbf{1})$ from a reaction mixture containing enzyme preparation of B. pumilus mutant BG2532. A reaction mixture containing $1 \mathrm{~g}$ of $\mathrm{D}$-glyceraldehyde, $1 \mathrm{~g}$ of DL-acetoin, $16 \mathrm{mmol}$ of Tris- $\mathrm{HCl}$ buffer ( $\mathrm{pH} \mathrm{8.0),} 1 \mathrm{mmol}$ of $\mathrm{MgCl}_{2}, 0.1 \mathrm{mmol}$ of TPP, $0.4 \mathrm{mmol}$ of EDTA, and $20 \mathrm{ml}$ of partially purified enzyme solution of the mutant BG2532 (460 mg of protein) in a total volume of $200 \mathrm{ml}$ was incubated at $37^{\circ} \mathrm{C}$ for $20 \mathrm{hr}$. After incubation, methanol ( 3 vol.) was added to the reaction mixture, and the precipitate formed was removed by centrifugation. Methanol was removed by evaporation under reduced pressure. This methanol treatment was repeated two more times. Then the solution was concentrated to a syrup, and ethanol ( $3 \mathrm{vol}$.) was added to the syrup. After the precipitate had been removed by centrifugation, the supernatant was concentrated in vacuo to a syrup, which was chromatographed on a column $(2.6 \times 40 \mathrm{~cm})$ of cellulose with solvent $\mathbf{B}$. The fractions containing compound $\mathbf{1}$ were concentrated, and the residue was crystallized from ethyl acetate to give $1(670 \mathrm{mg}), \mathrm{mp} 62 \sim 63^{\circ} \mathrm{C},[\alpha]_{\mathrm{D}}+33.6^{\circ}$ $\left(c=1, \mathrm{H}_{2} \mathrm{O}\right)$. IR $v_{\max }^{\mathrm{Nujol}} \mathrm{cm}^{-1}: 1710(\mathrm{C}=\mathrm{O}) . \operatorname{PMR}\left(\mathrm{D}_{2} \mathrm{O}\right) \delta$ : $1.64,1.69,2.50$ (total $3 \mathrm{H}$, three singlets in the ratio $\left.6: 20: 72, \mathrm{C}-\mathrm{CH}_{3}\right), 3.75 \sim 4.70(4 \mathrm{H}, \mathrm{m})$. Anal. Found: C, 45.08; $\mathrm{H}, 7.52$. Calcd. for $\mathrm{C}_{5} \mathrm{H}_{10} \mathrm{O}_{4}: \mathrm{C}, 44.77 ; \mathrm{H}, 7.51 \%$. PC: $R f 0.60$ (solvent A), 0.52 (solvent $\mathrm{B}$ ). It reduced alkaline silver nitrate and alkaline triphenyltetrazolium chloride, and gave greenish orange with vanillinperchloric acid ${ }^{21)}$ and yellow with orcinol-ferric chloridehydrochloride. TLC: $R f 0.59$ (solvent B), 0.43 (solvent C).

Tri-O-acetyl-1-deoxy-D-threo-pentulose (2). Compound $1(20 \mathrm{mg})$ was dissolved in a mixture of dry pyridine $(0.65 \mathrm{ml})$ and acetic anhydride $(0.5 \mathrm{ml})$. The solution was heated at $80^{\circ} \mathrm{C}$ for $10 \mathrm{~min}$ and stood overnight at room temperature, and then methanol $(10 \mathrm{ml})$ was added. The mixture was repeatedly evaporated with toluene. The residue was extracted with chloroform, and the chloroform extract was evaporated to give a syrup. The syrup was further purified by silica gel column chromatography $(1.1 \times 55 \mathrm{~cm})$ with solvent E. Fractions $(2 \mathrm{ml})$ were collected and analyzed by TLC with solvent E. Compound 2 was isolated by evaporation from fractions $48 \sim 66$ as a syrup $(14 \mathrm{mg}),[\alpha]_{\mathrm{D}}+44^{\circ}\left(c=1, \mathrm{CHCl}_{3}\right) . \operatorname{PMR}\left(\mathrm{CDCl}_{3}\right) \delta$ : $2.03\left(3 \mathrm{H}, \mathrm{s}, \mathrm{COCH}_{3}\right), 2.06\left(3 \mathrm{H}, \mathrm{s}, \mathrm{COCH}_{3}\right), 2.20(6 \mathrm{H}, \mathrm{s}$, $\left.2 \times \mathrm{COCH}_{3}\right), 4.10 \sim 4.40(2 \mathrm{H}, \mathrm{m}), 5.25(1 \mathrm{H}, \mathrm{d}, J=3.5 \mathrm{~Hz})$, $5.50 \sim 5.70(1 \mathrm{H}, \mathrm{m}) . \mathrm{MS} m / z: 261\left(\mathrm{M}^{+}+1\right), 260\left(\mathrm{M}^{+}\right)$. TLC: $R f 0.52$ (solvent D), 0.30 (solvent $\mathrm{E}$ ), 0.80 (solvent F).

Preparation of tetra-O-acetyl-1-deoxy-D-lyxitol (3)*3 and tetra-O-acetyl-1-deoxy-D-xylitol (4) from 1. Compound $1(160 \mathrm{mg})$ was dissolved in a $3 \%$ aqueous solution of sodium borohydride $(10 \mathrm{ml})$. The solution was kept for $1 \mathrm{hr}$ at room temperature, passed through a column of ion exchange resin IR-120 $\left(\mathrm{H}^{+}\right)$, and concentrated by repeated addition and evaporation of methanol under reduced pressure to give a syrupy residue. The residue was then dissolved in a mixture of pyridine $(1.5 \mathrm{ml})$ and acetic anhydride $(1.0 \mathrm{ml})$, which was heated at $80^{\circ} \mathrm{C}$ for $30 \mathrm{~min}$ and stood for $4 \mathrm{hr}$ at room temperature. Methanol $(10 \mathrm{ml})$ was added to the solution, and the mixture was repeatedly evaporated with toluene. The residue was chromatographed on a silica gel column $(1.2 \times$ $50 \mathrm{~cm})$ and eluted with solvent $\mathrm{G}$. Fractions $(5 \mathrm{ml})$ were collected and analyzed by TLC with solvent $\mathrm{G}$.

Compound 3 was isolated by evaporation from fractions $72 \sim 90$ as an amorphous material $(98 \mathrm{mg}),[\alpha]_{\mathrm{D}}$ $+46.3^{\circ}\left(c=1, \mathrm{CHCl}_{3}\right)$. PMR $\left(\mathrm{CDCl}_{3}\right) \delta: 1.22(3 \mathrm{H}, \mathrm{d}, J=$ $\left.6.0 \mathrm{~Hz}, \mathrm{CH}-\mathrm{CH}_{3}\right), 2.05\left(6 \mathrm{H}, \mathrm{s}, 2 \times \mathrm{OCOCH}_{3}\right), 2.08$ and 2.10 (each $\left.3 \mathrm{H}, \mathrm{s}, \mathrm{OCOCH}_{3}\right), 3.93(1 \mathrm{H}, \mathrm{dd}, J=10.0 \mathrm{~Hz})$, $4.35(1 \mathrm{H}, \mathrm{dd}, J=10.0 \mathrm{~Hz}), 5.00 \sim 5.40(3 \mathrm{H}, \mathrm{m})$. Anal. Found: C, 51.40; H, 6.70. Calcd. for $\mathrm{C}_{13} \mathrm{H}_{20} \mathrm{O}_{8} ; \mathrm{C}, 51.31$; $\mathrm{H}, 6.63 \%$. TLC: $R f 0.46$ (solvent D), 0.25 (solvent G).

Compound 4 was isolated similarly from fractions $96 \sim 124$ as a syrup $(64 \mathrm{mg}),[\alpha]_{\mathrm{D}}+9.2^{\circ}\left(c=1, \mathrm{CHCl}_{3}\right)$. $\operatorname{PMR}\left(\mathrm{CDCl}_{3}\right) \delta: 1.20\left(3 \mathrm{H}, \mathrm{d}, J=6.0 \mathrm{~Hz}, \mathrm{CH}-\mathrm{CH}_{3}\right), 2.02$, 2.04, 2.07 and 2.12 (each $\left.3 \mathrm{H}, \mathrm{s}, \mathrm{OCOCH}_{3}\right), 3.95(1 \mathrm{H}$, dd, $J=10.0 \mathrm{~Hz}), 4.26(1 \mathrm{H}, \mathrm{dd}, J=10.0 \mathrm{~Hz}), 4.90 \sim 5.40(3 \mathrm{H}$, m). Anal. Found: C, 51.40; H, 6.79. Calcd. for $\mathrm{C}_{13} \mathrm{H}_{20} \mathrm{O}_{8}$; C, $51.31 ; \mathrm{H}, 6.63 \%$. TLC: Rf 0.36 (solvent D), 0.20 (solvent $\mathrm{G}$ ).

Isolation of $\mathrm{L}-D T P(5)$ from the reaction mixture containing an enzyme preparation of the mutant BG2532. A reaction mixture containing $1 \mathrm{~g}$ of $\mathrm{L}$-glyceraldehyde and $1 \mathrm{~g}$ of DL-acetoin was treated similarly to compound 1 . A thick syrup obtained was applied to a column $(2.6 \times 45 \mathrm{~cm})$ of cellulose with the same solvent used in the isolation of $\mathbf{1}$. The fractions containing 5 were concentrated. The resudue was crystallized from ethyl acetate to give $5(417 \mathrm{mg}), \mathrm{mp}$ $63 \sim 65^{\circ} \mathrm{C},[\alpha]_{\mathrm{D}}-33^{\circ}\left(c=1, \mathrm{H}_{2} \mathrm{O}\right)$. Anal. Found: C, 44.44; $\mathrm{H}$, 7.66. Calcd. for $\mathrm{C}_{5} \mathrm{H}_{10} \mathrm{O}_{4} ; \mathrm{C}, 44.77 ; \mathrm{H}, 7.51 \%$. PMR and IR spectra, $R f$ values on PC and TLC and color reactions were identical with those of $\mathbf{1}$.

Tri-O-acetyl-1-deoxy-L-threo-pentulose (6). The acetylation of $20 \mathrm{mg}$ of compound $\mathbf{5}$ with acetic anhydride and pyridine and purification by silica gel column chromatography with solvent $\mathrm{E}$ yielded the syrupy acetyl derivative 6 $(18 \mathrm{mg}),[\alpha]_{\mathrm{D}}-43^{\circ}\left(c=1, \mathrm{CHCl}_{3}\right)$. PMR spectrum, mass spectrum and $R f$ values on TLC were identical to those of 2.

Preparation of tetra-O-acetyl-1-deoxy-L-lyxitol (7)*4 and tetra-O-acetyl-1-deoxy-L-xylitol (8) from $\mathbf{5}$. Compound $\mathbf{5}$ $(200 \mathrm{mg})$ was reduced with sodium borohydrate, acetylated, and purified by silica gel column chromatography $(1.2 \times 50 \mathrm{~cm})$ with solvent $\mathrm{G}$.

*3 Systematic name: Tetra- $O$-acetyl-5-deoxy-D-arabinitol.

*4 Systematic name: Tetra- $O$-acetyl-5-deoxy-L-arabinitol. 
Compound 7 was isolated by evaporation from fractions $70 \sim 88$ as a syrup $(126 \mathrm{mg}),[\alpha]_{\mathrm{D}}-41^{\circ}\left(c=1, \mathrm{CHCl}_{3}\right)$. PMR spectrum and $R f$ values on TLC were identical with those of compound 3. Anal. Found: C, 51.47; H, 6.77. Calcd. for $\mathrm{C}_{13} \mathrm{H}_{20} \mathrm{O}_{8} ; \mathrm{C}, 51.31 ; \mathrm{H}, 6.63 \%$.

Compound $\mathbf{8}$ was isolated similarly from fractions $92 \sim 110$ as a syrup $(75 \mathrm{mg}),[\alpha]_{\mathrm{D}}-8.8^{\circ}\left(c=2, \mathrm{CHCl}_{3}\right)$. PMR spectrum and $R f$ values on TLC were identical with those of compound 4. Anal. Found: C, 51.33; H, 6.72. Calcd. for $\mathrm{C}_{13} \mathrm{H}_{20} \mathrm{O}_{8} ; \mathrm{C}, 51.31 ; \mathrm{H}, 6.63 \%$.

Isolation of 1 from a reaction mixture containing an enzyme preparation of E. coli IFO 13168. Reaction conditions were similar to those described in the isolation of $\mathbf{1}$ from the reaction mixture containing an enzyme preparation of the mutant BG2532 except that $1 \mathrm{~g}$ of sodium pyruvate was used instead of DL-acetoin. The method of isolation and purification of the reaction product of the $E$. coli enzyme preparation was also similar to that in the case of mutant BG2532. The product was obtained as a syrup $(45 \mathrm{mg}),[\alpha]_{\mathrm{D}}+26.2^{\circ}\left(c=1, \mathrm{H}_{2} \mathrm{O}\right)$. $R f$ values and color reactions on $\mathrm{PC}$ and $R f$ values on TLC were identical with those of the reaction product $\mathbf{1}$ formed by the mutant BG2532 enzyme preparation.

Isolation of 1 from reaction mixture containing enzyme preparation of B. subtilis IFO 13719. Reaction conditions and the methods of isolation and purification of the reaction product of the $B$. subtilis enzyme preparation were similar to those described in the case of $E$. coli except that $1 \mathrm{~g}$ of methylacetoin was used instead of sodium pyruvate. The product was obtained as a syrup $(22 \mathrm{mg})$, $[\alpha]_{\mathrm{D}}+30.1^{\circ}\left(c=1, \mathrm{H}_{2} \mathrm{O}\right) . R f$ values and color reactions on PC and $R f$ values on TLC were identical with those of the reaction product 1 formed by the mutant BG2532 enzyme preparation.

Acknowledgments. We wish to thank Dr. T. Iijima, Director of this Institute, for his encouragement and valuable discussions. Grateful acknowledgment is also made to Mrs. Ihomi Nishiura for her able assistance in this work and to the members of the Chemical Research laboratories of Takeda Chemical Industries for the physicochemical measurements.

\section{REFERENCES}

1) A. Yokota and K. Sasajima, Agric. Biol. Chem., 42, 2245 (1978).

2) A. Yokota and K. Sasajima, Agric. Biol. Chem., 47, 1545 (1983).

3) R. H. White, Biochemistry, 17, 3833 (1978).

4) R. H. White, Experimentia, 36, 637 (1980).

5) M. Therisod, J-C. Fischer and B. Estramareix, Biochem. Biophys. Res. Commun., 98, 374 (1981).
6) S. David, B. Estramareix, J-C. Fischer and M. Therisod, J. Am. Chem. Soc., 103, 7341 (1981).

7) S. David, B. Estramareix, J-C. Fischer and M. Therisod, J. Chem. Soc., Perkin Trans. 1, 2131 (1982).

8) W. L. Dills, Jr., W. M. L. Ho and T. R. Covey, J. Carbohydr. Nucleosides, Nucleotides, 8, 211 (1981).

9) L. Slechta and L. E. Johnson, J. Antibiotics, 29, 685 (1976).

10) H. Hoeksema and L. Baczynskeyj, J. Antibiotics, 29 , 688 (1976).

11) A. Ishizu, K. Yoshida and N. Yamazaki, Carbohydr. Res., 23, 23 (1972).

12) J-C. Fischer, D. Horton and W. Weckerle, Can. J. Chem., 55, 4078 (1977).

13) E. Zissis and N. K. Richtmyer, J. Am. Chem. Soc., 76, 5515 (1954).

14) E. Zissis and N. K. Richtmyer, J. Am. Chem. Soc., 75, 129 (1953).

15) G. M. Bollenback and L. A. Underkofler, J. Am. Chem. Soc., 72, 741 (1950).

16) A. N. de Belder and H. Weigel, Chem. Ind., 1689 (1964).

17) M. A. Burkhari, A. B. Foster, J. Lehmann and J. M. Webber, J. Chem. Soc., 2287 (1963).

18) K. Blumberg, A. Fuccello and T. van Es, Carbohydr. Res., 59, 351 (1977).

19) R. L. White and I. D. Spenser, J. Am. Chem. Soc., 101, 5102 (1979).

20) R. L. White and I. D. Spenser, J. Am. Chem. Soc., 104, 4934 (1982).

21) A. P. Maclennan, H. M. Randall and D. W. Smith, Anal. Chem., 31, 2020 (1959).

22) R. H. Bauerle, M. Freundlich, F. C. Stormer and H. E. Umbarger, Biochim. Biophys. Acta, 92, 142 (1964).

23) E. Juni and G. A. Heym, J. Biol. Chem., 218, 365 (1956).

24) I. Alkonyi, E. Bolygo, L. Gyocsi and D. Szabo, Eur. J. Biochem., 66, 551 (1976).

25) T. P. Singer and J. Pensky, Biochim. Biophys. Acta, 9, 316 (1952).

26) R. J. Bloom and W. W. Westerfeld, Biochemistry, 5, 3204 (1966).

27) E. Juni and G. A. Heym, J. Bacteriol., 71, 425 (1956).

28) A. Yokota and K. Sasajima, in preparation.

29) "Enzyme Nomenclature: Recommendations (1978) of the Nomenclature Committee of the International Union of Biochemistry," Academic Press Inc., New York (1979).

30) J. Iwakawa, H. Kobatake, I. Suzuki and H. Kushida, J. Chromatog., 193, 333 (1980).

31) R. V. Tomlinson, Biochim. Biophys. Acta, 148, 1 (1967).

32) O. H. Lowry, N. J. Rosebrough, A. L. Farr and R. J. Randall, J. Biol. Chem., 193, 265 (1951). 